\title{
Implementation of critical success factors in construction research and development process
}

\author{
U. Kulatunga', D. Amaratunga and R. Haigh \\ School of the Built Environment, The University of Salford, UK \\ *Corresponding Author: e-mail: U.Kulatunga@salford.ac.uk, Tel +440161 2956943
}

\begin{abstract}
Construction research and development (R\&D) process has a number of issues that affect its success. These issues imply that Critical Success Factors (CSFs) of construction R\&D process are not properly addressed. Not knowing CSFs could lead to not implementing them and not paying proper attention for them. The study investigates CSFs of construction R\&D process and their implementation/consideration during the $\mathrm{R} \& \mathrm{D}$ process. A comprehensive literature review was used first to develop construction R\&D process. CSFs and their implementation/consideration were evaluated by a questionnaire survey. Construction R\&D process was derived with four phases namely Initiation, Conceptualizing, Development and Launch and Management activities that support coordination and resourcing of R\&D process. Study revealed that, as a whole there is a gap between the importance of success factors against their implementation/consideration as majority of CSFs are not properly implemented compared to the importance attached to them.
\end{abstract}

Keywords: Construction R\&D process, Critical success factors, Implementation, Consideration

\section{Introduction}

Research and Development (R\&D) has been identified as an overarching strategy for construction industry to address its challenges (Barrett 2007; Hampson and Brandon, 2004) such as to improve the efficiency and effectiveness of construction processes and materials; address growing concerns of environmental considerations and health and safety issues; comply with sustainable development requirements; and address cost, time, and quality parameters of construction projects. Fairclough (2002) suggests that innovation driven by $R \& D$ as a way forward if the society needs to be benefited from a modern, efficient, high quality construction industry. Not limiting the importance within the UK, R\&D is being identified as a key factor which develops the construction industries worldwide (Fox and Skitmore, 2007).

Despite the importance of R\&D activities for the growth of the construction industry, there are number of issues, which affect its success. A low level of investment can be identified for UK construction R\&D when compared with countries like France, Japan and Scandinavia (Gann, 2000) and when compared with other sectors like manufacturing (Department for Business Enterprise and Regulatory Reform, 2007; Institute of Civil Engineers, 2006; DTI, 2006; Dulaimi et al, 2002; Fairclough, 2002; Seaden and Manseau, 2001; Laing, 2001; Egan, 1998). One of the main reasons for low investment is improper reporting of R\&D expenses (Seaden and Manseau, 2001) and inadequate mechanisms to evaluate the successfulness of activities (Lorch, 2000). People question the value of R\&D when clear links between its benefits and the financial commitments are not established. Further, when the expectations of the participants of construction R\&D activities are not met, a low level of contribution from industrial partners is evident (Barrett and Barrett, 2003). Moreover, lack of feedback on the progress and success of R\&D activities and lack of communication between the parties involved (Dulaimi et al, 2002) have reduced the interest and attraction for contributors to ongoing construction $R \& D$ activities. It is being evident that construction $R \& D$ activities lack effective communication, feedback and validation procedures, and coordination between the parties involved in the process (Gann, 2001; Lorch, 2000).

Above issues imply that factors that are critical for the success of construction R\&D process are not properly addressed. Lack of knowledge and understanding of Critical Success Factors (CSFs) could lead to repercussions of paying insufficient attention on them. Further, not knowing the CSFs could result in focusing on factors which are less important for the success of construction 
R\&D process. This highlights the value of proper identification of CSFs. Studies carried out in other disciplines suggest that there could be a gap between the factors that are important and those that are implemented (Sun and Wing, 2005) as lack of knowledge of the success factors could lead to lack of implementation/consideration in practice. Even though there are a number of studies carried out on identifying CSFs related to R\&D in other disciplines (see Cooper and Kleinschmidt, 2007; Sun and Wing, 2005; Roberts, 2002; Sawhney and Prandelli, 2000; Cooper, 1999; Lester, 1998), paucity of studies is evident in evaluating CSFs of construction $\mathrm{R} \& \mathrm{D}$ process and their actual implementation/consideration. Therefore, this study explores the implementation/consideration of CSFs in construction R\&D process.

The paper is structured as follows. Firstly, the paper derives phases of construction R\&D process via a comprehensive literature review. Secondly, it provides the research methods used for the study. Following this, CSFs of construction R\&D process are presented. Implementation/consideration of CSFs is analyzed next followed with a discussion based on the importance and implementation/consideration of CSFs of construction R\&D process.

\section{Construction Research and Development Process}

The life cycle of a new venture (new product/process/services) can be divided into a number of distinct phases. The exact division of these phases is governed by the complexities of the final output, management structure of the organization etc. (Aw, 2005). The development of a new venture can involve a number of activities which are carried out by multidisciplinary teams, different departments and are influenced by various decisions. By considering these factors Saren (1984) identifies five types of models that represent life-cycle of a new venture.

- departmental stage models: based on the departments or functions which hold responsibility for the tasks carried out in the innovation process;

- active stage model: based on the activities that are performed;

- decision stage model: represent the innovation process as a series of evaluation points to decide if the work should go ahead or be abandoned;

- conversion process model: based on the concept that the innovation process is a conversion of inputs to outputs; and

- response model: focuses on the individuals' or organisations' response to change of ideas or project proposals in terms of acceptance or rejection of ideas or proposals.

There are strengths and weaknesses within the above models. The departmental stage model has the disadvantage of handling the idea in isolation within departments, and is characterized by the lack of ownership of the idea (Lim et al, 2006). The involvement of cross functional expertise and activities carried out during each stage is identified in the active stage model. However, this model assumes straightforward progression without indicating any alternative paths available (Saren, 1984). Further, the activities are supported by relevant departments thus passing the tasks from one department to the next (Takeuchi and Nonaka, 1986). The activities are seen, therefore, as the responsibility of the departments, creating similar drawbacks to the departmental stage models. The decision stage model consists of specific decision points to evaluate the success of activities and can be incorporated in the department stage and active stage models. Saren (1984) claims that the aforementioned models indicate that the new venture moves in a rational manner. The conversion process model takes the standpoint that conversion of inputs to outputs avoids assigning the responsibility to separate departments (Hart and Baker, 1994), avoids the sequential approach and the presence of activities (Saren, 1984). The response model is based on the responses to a change of idea/proposal thus evaluating the factors which influence the decision to move ahead or to reject (Hart and Baker, 1994).

In addition to the above models which represent the involvement of different decisions, activities, departments, and responses, the life cycle of a new venture can be divided into number of distinctive phases. Pillai et al (2002) divide it into three phases: project selection phase (initial screening, detailed evaluation, project selection); project execution phase (effective resource management to accomplish project goals within the stipulated time and cost); and project implementation phase (focusing on customer satisfaction and return on investment). Further, there are number of models proposed by various authors depicting various activities in a new venture development (see Table 1). It is noticeable that the phases of those models proposed by different authors follow a similar pattern, whilst activities coincide with one another. 
Table 1: Phases and activities involved in new venture development

\begin{tabular}{|c|c|c|c|c|c|c|}
\hline & Snelson and Hart (1991) & Theije et al. (1998) & $\begin{array}{l}\text { Loch and Tapper } \\
(2000)\end{array}$ & Cooper (2001) & Price (2004) & Moultrie et al. (2006) \\
\hline Initiation & $\begin{array}{l}\text { Idea generation } \\
\text { Screening ideas }\end{array}$ & Concept stage & Generate idea & $\begin{array}{l}\text { Discover } \\
\text { scope }\end{array}$ & $\begin{array}{l}\text { Opportunity } \\
\text { recognition }\end{array}$ & Project generation \\
\hline Conceptualisation & $\begin{array}{l}\text { Concept development } \\
\text { Business analysis }\end{array}$ & $\begin{array}{l}\text { Specification stage } \\
\text { Basic design stage } \\
\text { Detail design stage }\end{array}$ & $\begin{array}{l}\text { Select fund } \\
\text { Generate concept } \\
\text { Define specs }\end{array}$ & Business case & $\begin{array}{l}\text { Opportunity } \\
\text { focusing } \\
\text { Commitment } \\
\text { of resources }\end{array}$ & $\begin{array}{l}\text { Requirement capture } \\
\text { Concept design }\end{array}$ \\
\hline Development & $\begin{array}{l}\text { Product development } \\
\text { Test marketing }\end{array}$ & Engineering stage & $\begin{array}{l}\text { Design } \\
\text { Test }\end{array}$ & $\begin{array}{l}\text { Develop } \\
\text { Test } \\
\text { Validate }\end{array}$ & Market entry & Implementation \\
\hline Launch & Commercialisation & & Launch & Launch & $\begin{array}{l}\text { Full Launch } \\
\text { and Growth }\end{array}$ & \\
\hline Maturity & & & & & $\begin{array}{l}\text { Maturity and } \\
\text { expansion } \\
\text { Liquidity } \\
\text { event }\end{array}$ & \\
\hline
\end{tabular}

By reviewing the characteristics of the models, the authors categorize the phases of development of new venture into four categories as Initiation, Conceptualization, Development and Launch (Figure 1).

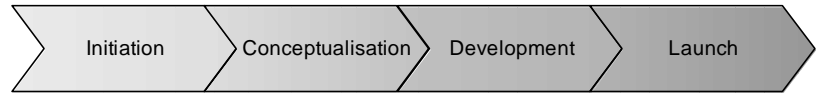

Figure 1: Phases of a new venture

The initiation phase involves idea generation regarding the new venture. This is followed by the conceptualization phase, which involves identifying the requirements of the parties involved and available resources and carrying out an analysis to check the feasibility of the new venture. The third phase involves the actual development and piloting of the new venture to test its validity. Finally the product will be launched at the launch phase. Some models consider a maturity phase where they examine the effect of the new venture on the market (see Price, 2004). Table 1 summarizes leading models of new venture development in relation to the identified four categories.

For the new venture to be successful within its life cycle, it requires a number of management roles, such as effective coordination of activities, communication, resource management and evaluation of output against the goals. By combining the phases of the new venture with the management activities that R\&D process needs for its success, authors derived R\&D process as shown in Figure 2.

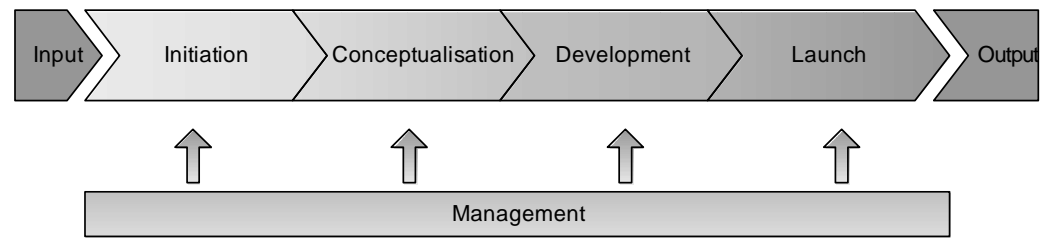

Figure 2: Construction R\&D process

When designing the R\&D process pertaining to this study, the concepts of "active stage" and "conversion" models were used (see Saren, 1984). Agreeing with Saren (1984) the authors also believe that the R\&D process should not be a rational or sequential one. Nevertheless, the authors believe that the identification of activities involved within the phases of R\&D process would help to prioritize them and lead to the successful accomplishment of them. The identification of activities involved during different phases would facilitate effective controlling and monitoring of the activities. It ensures the establishment of milestones and short term goals for their accomplishment, during a particular phase, and direction of the team members towards those goals. Though it is recommended to overcome the phase based approach and to integrate the phases, Sun and Wing (2005) comment that such integration could dilute the essential activities involved in R\&D work. Thus, the model designed for this study combines the characteristics of the active stage and conversion process models acknowledging the iterative processes, while representing the activities involved within each phase for ease of understanding of the R\&D work. Below diagram shows the issues (Refer Section 1) mapped against the construction R\&D process. 


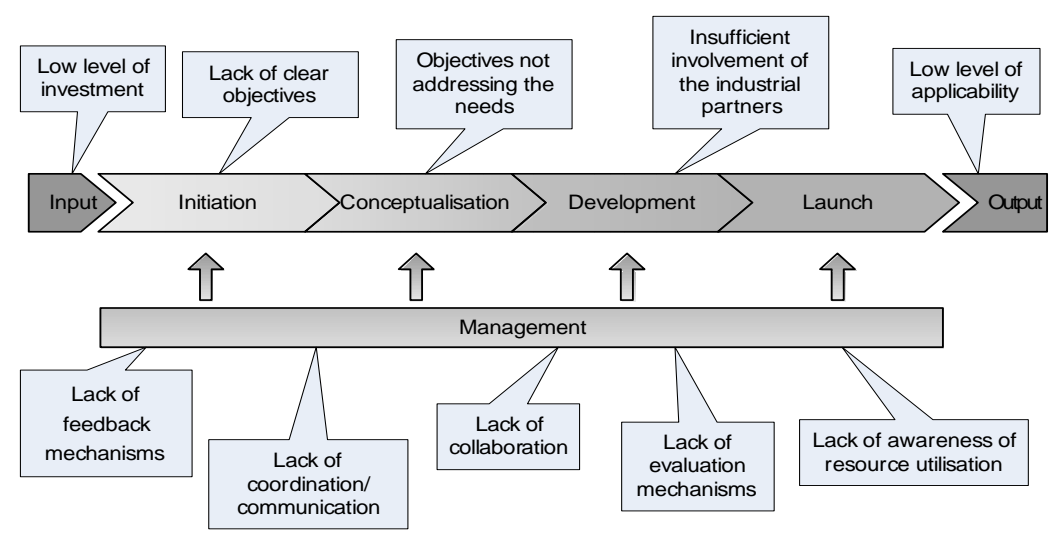

Figure 3: Issues within the construction R\&D process

Having identified the construction R\&D process, next section discusses the research methodology used form the study.

\section{Research Methodology}

\subsection{Data Collection}

The scope of the study is based on collaborative construction R\&D activities carried out between universities and industry. University-industry partnerships are acknowledged as a better way of carrying out construction research activities as they blend theory with practice to gain much success for the research effort (Gilkinson and Barrett, 2004; Calvert and Patel, 2003). During the first stage of the study, a comprehensive literature review was carried out to derive construction R\&D process. The development of the R\&D process critically evaluated new product development models and their characteristics (Refer Section 2). During the second stage of the study, identification of CSFs of construction R\&D process and their actual implementation/consideration was evaluated. To identify CSFs related to construction R\&D process, 13 semi-structured interviews were carried out (five principal investigators, five researchers and three industrial partners). By using NVivo software, the interview transcripts were coded to identify the success factors revealed by the interviewees. In addition to the semi-structured interviews, an extensive literature review was carried out on the CSFs in other disciplines. Success factors gathered from empirical investigation via semi-structured interviews and literature review were combined to prepare the questionnaires (Refer Table 2 for the response rate of the questionnaire survey). Within the questionnaire, the success factors were structured according to the phase of the construction $\mathrm{R} \& \mathrm{D}$ process derived from the literature review namely Initiation, Conceptualization, Development, Launch and for Management.

Table 2: Response rate for the questionnaire survey

\begin{tabular}{|l|l|l|l|}
\hline Category & $\begin{array}{l}\text { Number of } \\
\text { questionnaires } \\
\text { sent }\end{array}$ & $\begin{array}{l}\text { Number of } \\
\text { responses } \\
\text { received }\end{array}$ & Response rate \\
\hline $\begin{array}{l}\text { Principal Investigators: represent the university and manage and } \\
\text { lead the R\&D process } \quad \text { \& }\end{array}$ & 34 & $62 \%$ \\
$\begin{array}{l}\text { Researchers: represent the University and carries out research work } \\
\text { related to the project }\end{array}$ & $\begin{array}{l}\text { Industrial Partners: representatives from construction } \\
\text { organizations who contributes to the R\&D process }\end{array}$ & 26 & $35 \%$ \\
\hline
\end{tabular}

Both importance and implementation/consideration of success factors during their lifecycle was gathered from the questionnaire by using five scale Likert scales (Refer Table 3). The Likert scale to evaluate importance of success factors comprised of Very Important, Important, Moderately Important, Of the little Important and Unimportant where as the Likert scale to evaluate implementation/consideration of success factors comprised of Always, Very Often, Sometimes, Rarely and Never (Refer Table 3). In addition to the above values, no opinion/not applicable columns were added to both Likert scales to avoid respondents giving incorrect answers due to lack of knowledge or opinion for a particular question (Krosnick, 2002). 
Table 3: Sample of the questionnaire survey indicating the format and values assigned for Likert scale

\begin{tabular}{|c|c|c|c|c|c|c|c|c|c|c|c|c|}
\hline \multicolumn{13}{|c|}{$\begin{array}{l}\text { 1. Initiation Phase: This involves the idea generation to select the most suitable option for a research project } \\
\text { The extent of importance } \\
\text { The extent of consideration/ implementation }\end{array}$} \\
\hline 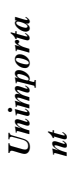 & 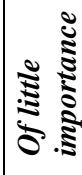 & 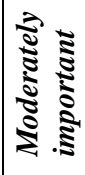 & 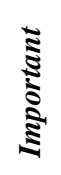 & 5 & 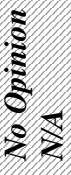 & & 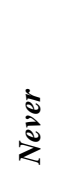 & 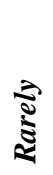 & 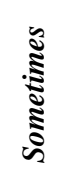 & 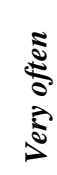 & $\frac{\hat{\hat{E}}}{\hat{z}}$ & 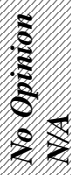 \\
\hline 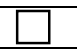 & $\square$ & $\square$ & $\square$ & $\square$ & 1 & Understand the market and its dynamics & $\square$ & 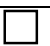 & $\square$ & $\square$ & $\square$ & \\
\hline $\mathrm{E}$ & $\square$ & $\square$ & $\square$ & $\square$ & 0 & Establish the research problem clearly & $\square$ & & $\square$ & $=$ & & \\
\hline 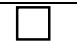 & $\square$ & $\square$ & $\square$ & $\square$ & 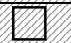 & Selecting a competent team & $\square$ & $\square$ & $\square$ & $\square$ & & \\
\hline 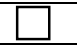 & $\square$ & $\square$ & $\square$ & $\square$ & 0 & Leadership of the principal investigator & $\square$ & $\square$ & $\square$ & $\square$ & $\bar{L}$ & \\
\hline 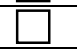 & $\square$ & $\square$ & $\square$ & $\square$ & 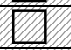 & Commitment of the principal investigator & $\square$ & $\square$ & $\square$ & $\square$ & 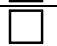 & \\
\hline $\bar{E}$ & $\square$ & $\square$ & $\square$ & $\square$ & 0 & Consider funding bodies' requirements & $\square$ & $\square$ & $\square$ & $\square$ & 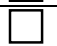 & 4 \\
\hline$\square$ & $\square$ & $\square$ & $\square$ & $\square$ & 1 & Consider industrial partners' requirements & $\square$ & $\square$ & $\square$ & $\square$ & 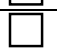 & $x$ \\
\hline$\square$ & $\square$ & $\square$ & $\square$ & $\square$ & 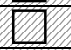 & Consider researchers' requirements & $\square$ & $\square$ & $\square$ & $\square$ & 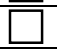 & $x$ \\
\hline$\square$ & $\square$ & $\square$ & $\square$ & $\square$ & 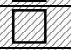 & Other (please specify) & $\square$ & $\square$ & $\square$ & $\square$ & $\square$ & 1 \\
\hline$\square$ & $\square$ & $\square$ & $\square$ & $\square$ & 1 & & $\square$ & $\square$ & $\square$ & $\square$ & $\square$ & 1 \\
\hline
\end{tabular}

\subsection{Data Analysis}

CSFs of construction R\&D process were evaluated by considering the responses received regarding the importance of success factors. Responses received for the questionnaire survey regarding the importance of success factors were subjected to two filtering stages to evaluate CSFs of construction R\&D process. During the first filtering stage, success factors that received an overall mean value (total mean value received from principle investigators, researchers and industrial partners) less than four were excluded from further analysis. This filtering was done on the premise that mean value less than four indicates unimportant (value 1), of the little important (value 2) or moderately important (value 3) success factors (refer Table 3 for the values assigned for the questionnaire survey). For those success factors obtained an overall mean value including four and above were subjected to the second filtering stage by using the Wilcoxon signed rank test. The Wilcoxon signed rank test is a non-parametric method to test the differences of two related variables when the subject (dependant category) is measured on two occasions or under different conditions (Hill and Lewicki, 2007; Pallant, 2001). By taking a consecutive pair of data, the Asymptotic significance was calculated. The Asymptotic significance shows an estimate of the significance of differences within attributes being tested (Pallant, 2001). Generally, Asymptotic significance less than 0.05 is considered as indicating a significant difference between the attributes being tested. Accordingly, the paired data which showed an Asymptotic significance $<0.05$ was considered as responses having a significant difference regarding the importance of the success factors, hence such factors were considered as not critical for the success of construction R\&D process (refer to Table 4 for total mean values and Asymptotic significance of CSFs).

After identifying the CSFs, their implementation/consideration during the construction R\&D process was done by analyzing the total mean values obtained from the questionnaire regarding the "implementation of success factors" (refer to Table 4 for the mean values obtained for the implementation/consideration of success factors). The above section discussed the research methodology used for the study. Section below provides the CSFs of construction R\&D process.

\section{Findings}

4.1 Critical success factors of construction research and development

The study developed a number of CSFs for construction R\&D process by analyzing the questionnaire survey. Summary of CSFs of construction R\&D is presented in Table 4.

Table 4: CSFs and their implementation/consideration during the R\&D process

\begin{tabular}{|l|r|r|r|r|r|r|}
\hline & \multicolumn{4}{|l|}{$\begin{array}{l}\text { Implementation/ } \\
\text { Initial Phase }\end{array}$} & \multicolumn{2}{l|}{$\begin{array}{l}\text { Importance of the success } \\
\text { factors } \\
\text { the success } \\
\text { factors }\end{array}$} \\
\hline Establish the research problem clearly & Mean & Rank & $\begin{array}{l}\text { Asymptotic } \\
\text { Significance }\end{array}$ & Mean & Rank \\
\hline Commitment of the principle investigator & 4.79 & 1 & N/A & 3.97 & 2 \\
\hline Select a competent team & 4.56 & 2 & 0.06 & 3.80 & 3 \\
\hline
\end{tabular}


Table 4 (cont'd): CSFs and their implementation/consideration during the R\&D process

\begin{tabular}{|c|c|c|c|c|c|}
\hline \multirow[t]{2}{*}{ Initial Phase (cont'd) } & \multicolumn{3}{|c|}{$\begin{array}{l}\text { Importance of the success } \\
\text { factors }\end{array}$} & \multicolumn{2}{|c|}{$\begin{array}{l}\text { Implementation/ } \\
\text { consideration of } \\
\text { the success } \\
\text { factors }\end{array}$} \\
\hline & Mean & Rank & $\begin{array}{l}\text { Asymptotic } \\
\text { Significance }\end{array}$ & Mean & Rank \\
\hline Leadership of the principle investigator & 4.28 & 4 & 0.08 & 3.69 & 6 \\
\hline Consider industrial partners' requirements & 4.27 & 5 & 0.99 & 3.72 & 4 \\
\hline Consider funding bodies' requirements & 4.26 & 6 & 0.87 & 4.02 & 1 \\
\hline Understand the market and its dynamics & 4.13 & 7 & 0.45 & 3.72 & 5 \\
\hline Consider researchers' requirements & 3.79 & 8 & & 3.66 & 7 \\
\hline
\end{tabular}

\section{Conceptualising Phase}

\begin{tabular}{|c|c|c|c|c|c|}
\hline Check the feasibility of the project & 4.75 & 1 & N/A & 3.82 & 3 \\
\hline Commitment of the principle investigator & 4.57 & 2 & 0.07 & 3.77 & 5 \\
\hline Committed and cooperative team members & 4.53 & 3 & 0.55 & 3.60 & 9 \\
\hline Establish clear and realistic goals/ deliverables/ milestones & 4.51 & 4 & 0.99 & 3.79 & 4 \\
\hline Adequate resources/financial support & 4.44 & 5 & 0.52 & 3.75 & 6 \\
\hline $\begin{array}{l}\text { Allocation of responsibilities to team members inline with } \\
\text { competencies }\end{array}$ & 4.39 & 6 & 0.61 & 3.44 & 12 \\
\hline Establish a plan to disseminate research results & 4.39 & 7 & 1 & 3.90 & 2 \\
\hline Leadership of the principle investigator & 4.31 & 8 & 0.58 & 3.67 & 7 \\
\hline Having a skilled team & 4.30 & 9 & 0.76 & 3.66 & 8 \\
\hline Establish clear method to measure success & 4.30 & 10 & 1 & 3.20 & 16 \\
\hline Consider industrial partners' requirements & 4.30 & 11 & 0.95 & 3.52 & 10 \\
\hline Consider funding bodies' requirement & 4.28 & 12 & 0.97 & 3.98 & 1 \\
\hline Absence of lengthy bureaucracy & 4.00 & 13 & 0.03 & 2.93 & 18 \\
\hline Early involvement of industrial partners & 4.00 & 14 & & 3.34 & 13 \\
\hline Comprehensive briefing process & 3.98 & 15 & & 3.33 & 14 \\
\hline Recognition for team members & 3.92 & 16 & & 3.21 & 15 \\
\hline Consider researchers' requirements & 3.84 & 17 & & 3.46 & 11 \\
\hline Fast decision making process & 3.72 & 18 & & 3.18 & 17 \\
\hline
\end{tabular}

Development Phase

\begin{tabular}{|c|c|c|c|c|c|}
\hline Committed and cooperative team members & 4.59 & 1 & N/A & 3.64 & 6 \\
\hline Commitment of the principle investigator & 4.57 & 2 & 0.83 & 3.93 & 2 \\
\hline Adequate resources/financial support & 4.56 & 3 & 0.91 & 3.79 & 3 \\
\hline Having a skilled team & 4.51 & 4 & 0.55 & 3.57 & 7 \\
\hline Meet funding bodies' requirements & 4.51 & 5 & 0.99 & 3.93 & 1 \\
\hline Share a common understanding about the work & 4.41 & 6 & 0.29 & 3.52 & 8 \\
\hline Well establish operational procedure & 4.39 & 7 & 0.91 & 3.36 & 12 \\
\hline Meet industrial partners' requirements & 4.39 & 8 & 0.98 & 3.46 & 9 \\
\hline Momentum/ motivation of the team & 4.38 & 9 & 0.91 & 3.39 & 10 \\
\hline Flexibility and responsiveness to change & 4.38 & 10 & 1 & 3.38 & 11 \\
\hline
\end{tabular}


Table 4 (cont'd): CSFs and their implementation/consideration during the R\&D process

\begin{tabular}{|c|c|c|c|c|c|}
\hline \multirow[t]{2}{*}{ Development Phase (cont'd) } & \multicolumn{3}{|c|}{$\begin{array}{l}\text { Importance of the success } \\
\text { factors }\end{array}$} & \multicolumn{2}{|c|}{$\begin{array}{l}\text { Implementation/ } \\
\text { consideration of } \\
\text { the success } \\
\text { factors }\end{array}$} \\
\hline & Mean & Rank & $\begin{array}{l}\text { Asymptotic } \\
\text { Significance }\end{array}$ & Mean & Rank \\
\hline Leadership of the principle investigator & 4.38 & 11 & 0.94 & 3.72 & 5 \\
\hline Absence of lengthy bureaucracy & 4.11 & 12 & 0.02 & 3.08 & 15 \\
\hline Meet researchers' requirements & 4.08 & 13 & & 3.75 & 4 \\
\hline Recognition for team members & 4.02 & 14 & & 3.21 & 13 \\
\hline Fast decision making process & 3.95 & 15 & & 3.10 & 14 \\
\hline Having a risk mitigation strategy & 3.95 & 16 & & 2.78 & 17 \\
\hline Testing the market & 3.92 & 17 & & 3.00 & 16 \\
\hline
\end{tabular}

Launch Phase

\begin{tabular}{|c|c|c|c|c|c|}
\hline Effective dissemination of the results & 4.52 & 1 & N/A & 3.54 & 4 \\
\hline Meet funding bodies' requirements & 4.49 & 2 & 0.73 & 3.90 & 1 \\
\hline Having a well established dissemination/ marketing plan & 4.48 & 3 & 0.88 & 3.33 & 6 \\
\hline Meet industrial partners' requirements & 4.40 & 4 & 0.46 & 3.64 & 2 \\
\hline Launch the output within the planned time frame & 4.36 & 5 & 0.93 & 3.41 & 5 \\
\hline Comprehensive project review and feedback & 4.05 & 6 & 0.03 & 3.28 & 7 \\
\hline Meet researchers' requirements & 3.89 & 7 & & 3.56 & 3 \\
\hline Refinement of the output after launch & 3.84 & 8 & & 3.00 & 8 \\
\hline
\end{tabular}

\section{Management}

\begin{tabular}{|c|c|c|c|c|c|}
\hline Effective communication & 4.70 & 1 & N/A & 3.59 & 2 \\
\hline Effective collaboration & 4.62 & 2 & 0.28 & 3.52 & 4 \\
\hline Effective planning, controlling, and organising of activities & 4.52 & 3 & 0.29 & 3.54 & 3 \\
\hline Continuous reviews & 4.48 & 4 & 0.53 & 3.66 & 1 \\
\hline Effective resource management & 4.34 & 5 & 0.19 & 3.31 & 6 \\
\hline Effective management of the people & 4.33 & 6 & 0.85 & 3.38 & 5 \\
\hline Having an external person to do reviews & 3.98 & 7 & & 3.16 & 7 \\
\hline Evaluating post delivery success & 3.95 & 8 & & 2.98 & 8 \\
\hline Having a separate project administrator & 3.43 & 9 & & 2.89 & 9 \\
\hline
\end{tabular}

* Success factors written in Italic letters are none-critical factors

Asymptotic Significance values are not shown for non-critical factors

For the detail descriptions about above CSFs, please refer Kulatunga et al. (2009).

\subsection{Implementation/consideration of critical success factors}

By considering overall mean values (Table 4) of CSFs and their implementation/consideration during the R\&D process Radar diagrams were prepared (Figure 4 to Figure 8). These figures compare the importance and implementation/consideration of success factors during initiation, conceptualizing, development and launch phases and at management. 


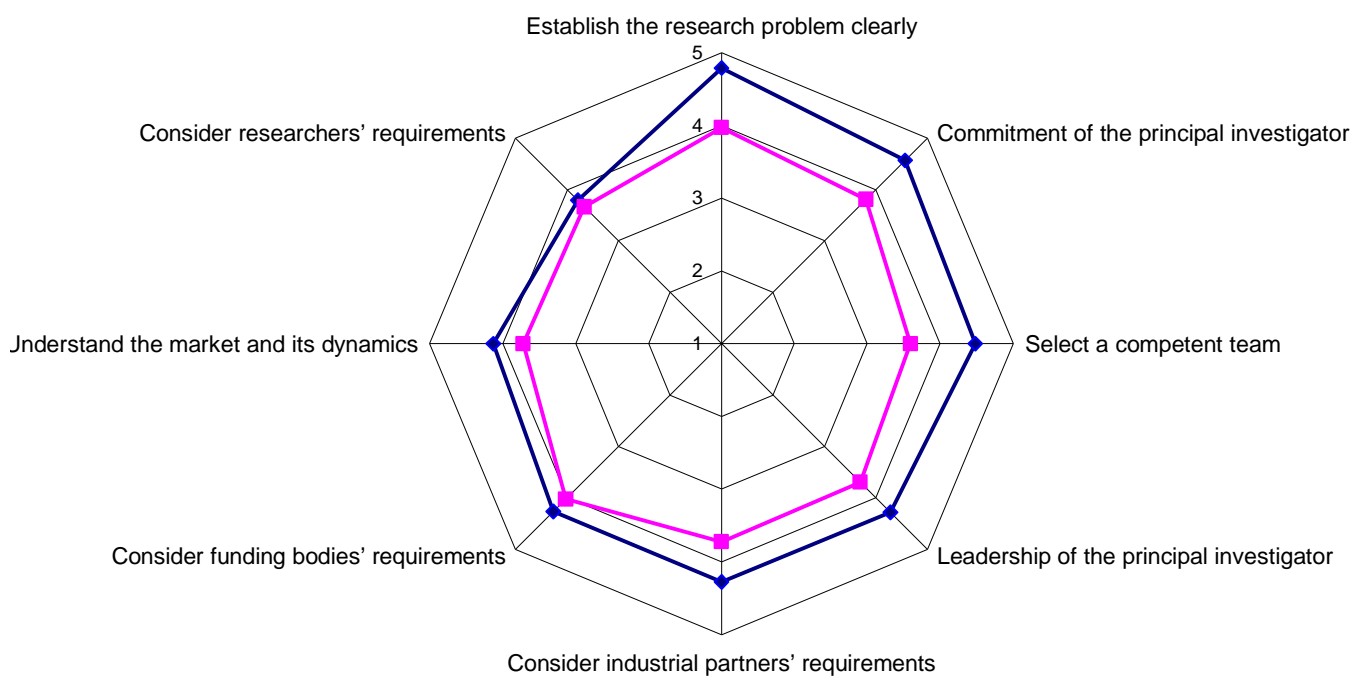

Importance of the success factors - - Implementation/consideration of the success factors

Figure 4: Comparison of the importance of success factors against their implementation/consideration at the initiation phase

At the initiation phase all the success factors except for "considering funding bodies' requirements" have obtained mean values less than 4 for their implementation/ consideration. It can be noted that "considering the funding bodies' requirements", "establishing the research problem clearly" and "commitment of the principal investigator" are being identified as the most implemented/considered factors while "selecting a competent team" and "considering researchers' requirements" as the least implemented/considered factors. Figure 5 illustrates the importance and implementation/consideration of success factors at the conceptualizing phase. Within this phase, all the success factors have acquired a mean value less than 4 for their implementation/ consideration. Nevertheless, similar to the initiation phase, "considering funding bodies' requirement" has been ranked as number one indicating higher consideration given it. "Establishing a plan to disseminate research results" and "checking the feasibility of the project" is ranked second and third respectively, while "a fast decision making process" and "absence of a lengthy bureaucracy" as the least implemented/considered factors.

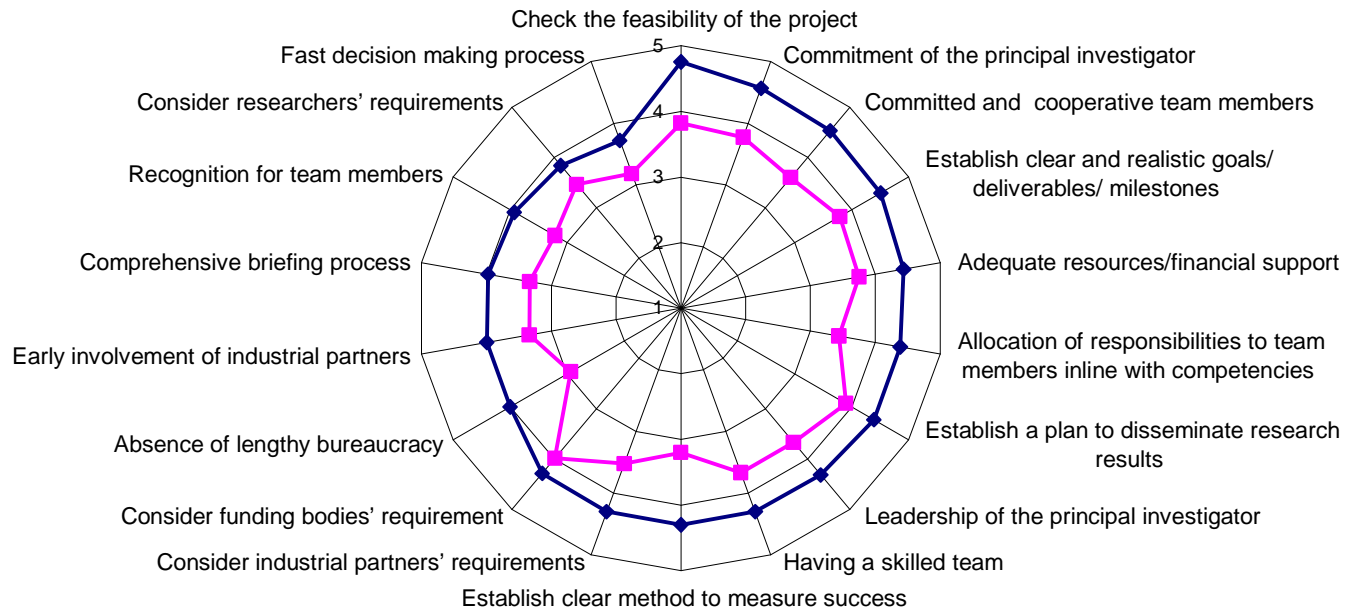

Importance of the success factors - -Implementation/consideration of the success factors

Figure 5: Comparison of the importance of success factors against their implementation/consideration at the conceptualizing phase 
Similar to the initiation and conceptualizing phases, all the success factors have obtained mean values of less than 4 at the implementation/consideration during the development phase (see Figure 6). Again, "addressing the requirements of the funding body" has been ranked number one, while "commitment of the principal investigator" and "having adequate resources" have been ranked two and three according to their implementation/ consideration.

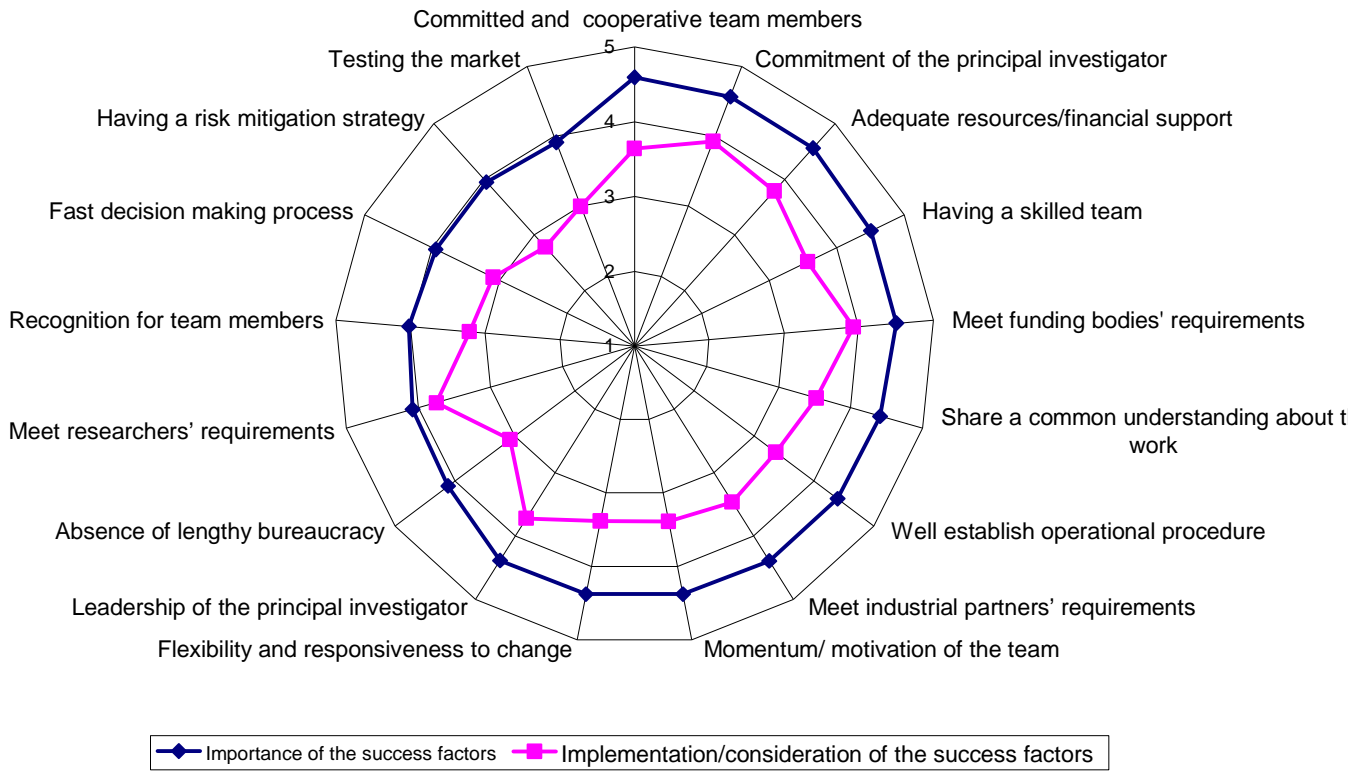

Figure 6: Comparison of the importance of success factors against their implementation/consideration at development phase

At launch, addressing the funding bodies' and industrial partners' requirements have been selected as the factors that were mostly implemented/ considered (see Figure 7). The success factors "refinement of the output after launch" and "carrying out project reviews and feedback" are identified as being the least implemented/considered factors. Corresponding to the other phases, at the launch phase also all the success factors obtained their mean values less than 4.

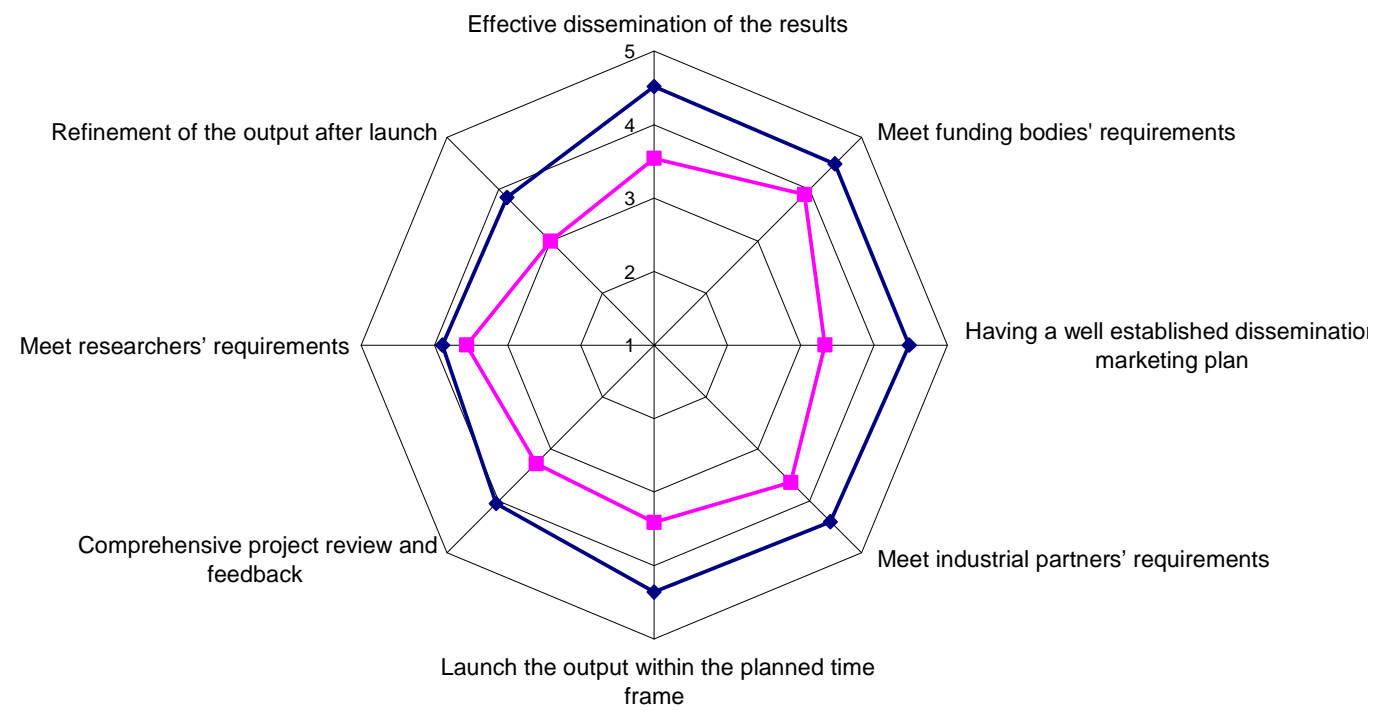

Importance of the success factors - Implementation/consideration of the success factors

Figure 7: Comparison of the importance of success factors against their implementation/consideration at the launch phase 
Carrying out continuous reviews and effective communication are identified as being the most implemented/considered success factors when managing the R\&D process (see Figure 8). "Engaging a separate person to undertake project administration work" and "evaluation of post delivery success" has been selected as the least implemented/considered factors.

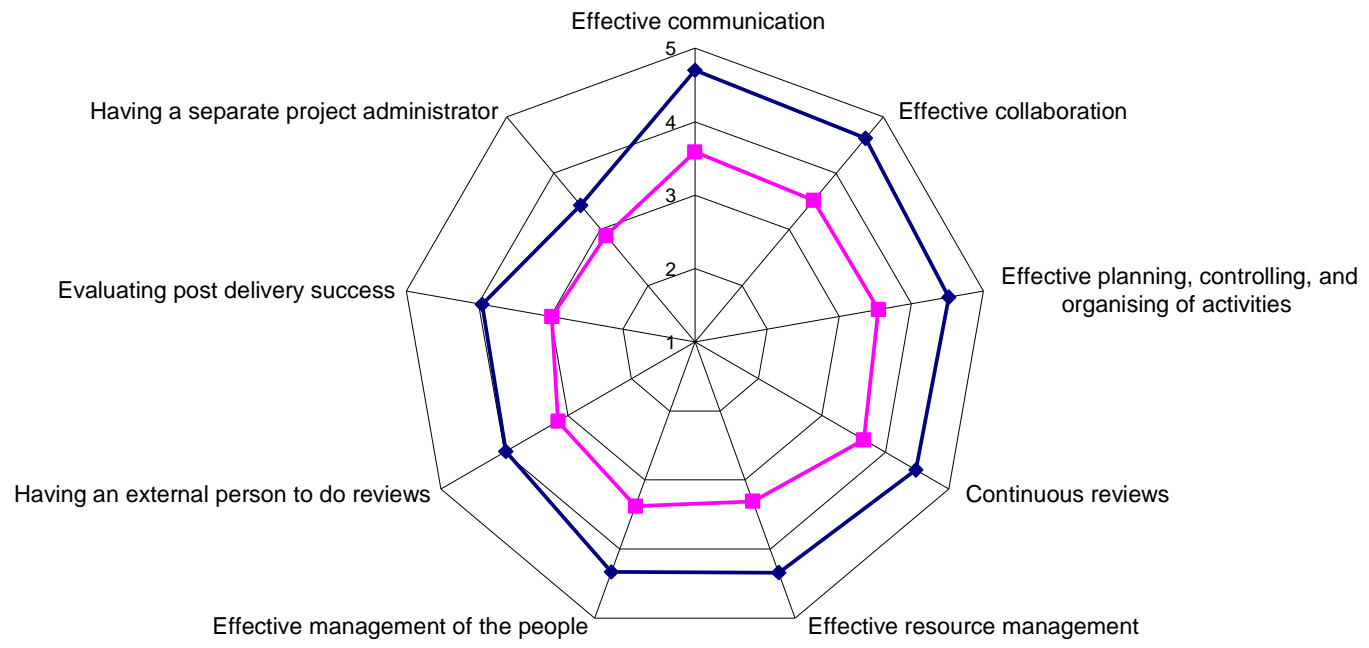

Importance of the success factors - Implementation/consideration of the success factors

Figure 8: Comparison of the importance of success factors against their implementation/consideration at project management

\section{Discussion}

Overall, the empirical data indicates that the majority of success factors (except for "considering the funding bodies' requirements") are not very often (value 4) or always (value 5) implemented/considered during the construction R\&D process but are implemented sometimes (value 3). This indicates that CSFs are not adequately implemented/considered during the actual process even though they are identified as important for the success of construction R\&D process. The success factors identified as non-critical (refer to Table 4), have generally been ranked low at the implementation/consideration (except for "meeting the researchers requirements" during the development and launch phases). This gives a positive correlation between the importance and implementation/consideration of non-critical success factors.

During the actual implementation of the R\&D process, the funding bodies' requirements were taken as the most considered factor (Refer Table 4). This indicates the prominence given in fulfilling the requirements of funding bodies as the satisfaction of funding bodies leads to safeguarding of future funding opportunities for construction R\&D projects. Though the empirical investigation of this study highly valued the importance of commitment of principal investigator for the R\&D process (Rank 2 at initiation, conceptualization and development phases), during the implementation stage of the R\&D project, the commitment of the principal investigator was not ranked highly when compared to its importance. In contrast to the findings of the empirical investigation of this study, Peansupap and Walker (2006) identify the influence of senior management for proper diffusion of innovation. Selecting a competent team during the initiation phase and having a skilled team during the conceptualizing and development phases obtained ranks below 7 (Refer to Table 4) indicating they are not given sufficient implementation/consideration during construction R\&D process. Similarly, having a multi-skilled team in order for a construction organization to be innovative was not given much attention in the study carried out by Manley and McFallan (2006).

Although "selecting a competent team" has been ranked third according to its importance at the initiation phase, it has been ranked eighth at the implementation. Similarly, factors "committed and cooperative team members" at the conceptualizing and development phases (rank 3 and 9, 1 and 6 respectively), "allocation of responsibilities to team members in line with competencies" at the conceptualizing phase (rank 6 and 12) have taken higher rankings for their importance when compared with their implementation. This indicated that these factors are not given due consideration during the implementation when compared to their importance. Accordingly, some factors showed an inconsistency between the importance and implementation based on their assigned ranks. Such inconsistency of CSFs based on the importance and implementation was identified in the study carried out by Sun and Wing (2005). 


\section{Conclusions}

The study investigated the CSFs and their implementation during construction R\&D process. Despite the importance of R\&D to construction industry, there are number of issue that hinders its success. This study suggests the identification of CSFs and evaluation of their implementation during the $R \& D$ process as a way forward to enhance success of construction $R \& D$ process. The study argued that identification of CSFs and their actual implementation/consideration during R\&D process could lead to giving proper attention for the factors that are highly important for the success of construction R\&D process. Study identified a number of CSFs of construction R\&D process from inception, conceptualizing, development and launch phases and at management. The results revealed that, when compared with the importance, it is seldom that almost all the CSFs are given enough attention during the actual implementation of the construction R\&D process. Identification of CSFs from the study provides a good foundation for their effective management of them to provide required resources and attention by concentrating on few critical factors that are required for the success of construction R\&D process. The fact revealed from the study that prominence attached to the importance of success factors were not given when it comes to their implementation during the construction $\mathrm{R} \& \mathrm{D}$ process will also help to pay more attention for the success factors during their actual implementation stage. As a way forward, it can be suggested to link CSFs with performance measures so that addressing performance measurement targets can ensure implementation of CSFs to enhance construction R\&D activities. Even though there are a number of studies carried out on identifying CSFs, they are based in other disciplines such as manufacturing etc. Thus, this study contributes to the theory by deriving construction $R \& D$ specific $C S F s$ and integrating them with the phases of the $R \& D$ process from initiation, conceptualising, development to launch and at the management of $R \& D$ activities. Evaluation of the actual implementation/consideration of CSFs contributed to management and practice by identifying the CSFs that are not implemented/considered properly during the construction R\&D process. The scope of the study is based on collaborative construction R\&D activities carried out between universities and industry. The findings derived from the study therefore can be generalized within collaborative construction R\&D activities between universities and industry. This can be identified as a limitation of the study.

\section{References}

Aw, K. C. 2005, Integrating quality and reliability assessment into product development process, International journal of quality and reliability management, Vol. 22 No. 5, pp. 518-530

Barrett, P. 2007, Revaluing Construction: a holistic model, Building Research and Information, Vol. 35 No.3, pp. 268-286

Barrett, S. P., and Barrett, L. C. 2003, Research as a kaleidoscope on practice, Construction management and economics, Vol. 21 No. 7, pp. 755-766

Calvert, J., and Patel, P. 2003, University- industry research collaborations in the UK: bibliometric trends, Science and public policy, Vol. 30 No. 2, pp. 85-96

Cooper, R.G. 1999, From experience: the invisible success factors in product innovation, Journal of Product Innovation and Management, Vol. 16 No. 2, pp. 115-133

Cooper, R.G. 2001, Winning at New Products: Accelerating the Process from Idea to Launch, $3^{\text {rd }}$ edition, Perseus publishing, Cambridge

Cooper, R.G., and Kleinschmidt, E.J. 2007, Winning businesses in product development: the critical success factors, Research Technology Management, Vol. 50 No. 3, pp. 52-66

Department for Business, Enterprise \& Regulatory Reform, 2007, Draft Strategy for Sustainable Construction, A consultation paper, (accessed: Feb 2008), available online at: http://www.berr.gov.uk/files/file40641.pdf

Dulaimi, M F., Ling, F.Y.Y., Ofori G., and De Silva N. 2002, Enhancing integration and innovation in construction, Building research and information, Vol. 30 No. 4, pp.237-247

Egan, J. 1998, Rethinking construction: Report from the construction task force, Department of the environment, transport and regions, UK

Fairclough, J., 2002, Rethinking construction innovation and research: A review of government $R$ and $D$ policies and practices, Department of Trade and Industry, London

Fox, P., and Skitmore, M. 2007, Factors facilitating construction industry development, Building Research and Information, Vol. 35 NO. 2, pp. $178-188$

Gann, D. M. 2001, Putting academic ideas into practice: technological progress and the absorptive capacity of construction organisations, Construction management and economics, Vol. 19 No.3, pp. 321-330

Gann, D.M. 2000, Building innovation, Thomas Telford, London

Gilkinson, N., and Barrett, P. 2004, The unanticipated impacts of research on practice, CIB world congress, $2^{\text {nd }}-7^{\text {th }}$ May, Canada

Hampson, K., and Brandon, P. 2004, Construction 2020: A vision for Australia's property and construction industry, CRC Construction Innovation, Australia

Hart, S. J., and Baker, M .J. 1994, The multiple convergent processing model of new product development, International marketing review, Vol. 11 No. 1, pp. 77-92 
Hill, T., and Lewicki, P. 2007, STATISTICS Methods and Applications. StatSoft, Tulsa, (accessed: February 2008), available from: http://www.statsoft.com/textbook/stathome.html

Institute of Civil Engineers, 2006, Infrastructure research priority, (accessed: March 2007), available from: http://www.ncrisp.org.uk/Publications/Infrastructure\%20Research\%20Priorities.pdf

Krosnick, J.A. 2002, The causes of no-opinion responses to attitude measures in surveys: They are rarely what they appear to be. In R.M. Groves, D.A. Dillman, J.L. Eltinge, \& R.J. A. Little (Eds), Survey nonresponse, John Wiley \& Sons, New York

Kulatunga, U, Amaratunga, D, and Haigh, R 2009, Critical Success Factors of Construction Research and Development, Construction Management and Economics, Vol. 27. No. 9, pp. 891-900

Laing, M. 2001, Yesterday, today and tomorrow - lessons from the past we can take forward into the future, Reading construction forum, Oxford

Lester, D.H., 1998, Critical success factors for new product development, Research Technology Management, Vol.41 No.1, pp.16-21

Lim, L. P. L., Garnsey, E., and Gregory, M. 2006, Product and process innovation in biopharmaceuticals: a new perspective on development, $R \& D$ Management, Vol. 36 No.1, pp. 27-36

Loch, C. H., and Tapper, U. A. S. 2000, R\&D performance measurement that are linked to strategy, working paper, INSEAD, (accessed $5^{\text {th }}$ March 2005), available from: http://ged.insead.edu/fichiersti/inseadwp2000/2000-14.pdf

Lorch, R. 2000, Improving the communication of academic research to the construction industry, Construction research and innovation strategy panel, (accessed 20 $0^{\text {th }} \quad$ February 2006), available online from: http://ncrisp.steelsci.org/Publications/9916frLo.pdf

Manley, K. and Mcfallan, S., 2006, Exploring the drivers of firm-level innovation in the construction industry, Construction Management and Economics, Vol.24 No. 9, pp.911-920.

Moultrie, J., Clarkson, P. J., and Probert, D, 2006, A tool to evaluate design performance in SMEs, International Journal of Productivity and Performance Management, Vol. 55 No. 3/4, pp. 184-216

Pallant, J. 2001, SPSS survival manual. A step by step guide to data analysis using SPSS for windows (Version 10-11). Open University Press, Buckingham

Peansupap, V. and Walker, D.H. T. 2006, Innovation diffusion at the implementation stage of a construction project: a case study of information communication technology, Construction Management and Economics, Vol. 24 No.3, pp. 321-332

Pillai, A. S., Joshi A., and Rao, K. S. 2002, Performance measurement of R\&D projects in a multi-project, International Journal of Project Management, Vol. 20 No. 2, pp. 165-177

Price, R. W. 2004, Road map to Entrepreneurial success: powerful strategies for building a high profit business, AMA-COM, New York.

Roberts, G. 2002, SET for success: The supply of people with science, technology, engineering, and mathematics skills, HM Treasury, UK

Saren, M. 1984, A classification of review models for the intra-firm innovation process, R\&D management, Vol. 14 No.1, pp.1124

Sawhney, M., and Prandelli, E. 2000, Communities of creation: managing distributed innovation in turbulent markets, California Management Review, Vol. 42 No.4, pp.45-69

Seaden, G., and Manseau, A. 2001, Public policy and construction innovation, Building research and information, Vol. 29 No.3, pp. 182-196

Snelson, P.A., and Hart, S. J. 1991, Product Policy: Perspectives on Success, in Baker, M. J. (Ed.), Perspectives on Marketing Management, Vol. 1, pp.193-225.

Sun, H., and Wing, W. 2005, Critical success factors for new product development in the Hong Kong toy industry, Technovation, Vol.25 No.3, pp.293-303

Takeuchi, H., and Nonaka, I. 1986, The New Product Development Game, Harvard Business Review, Vol. 64 No.1, pp. 137-46

Theije, S. M., Sander, P.C., and Brombacher, A. C. 1998, Reliability tests to control design quality: a case study, International Journal of Quality \& Reliability Management, Vol. 15 No. 6, pp. 599-618

\section{Bibliographical notes:}

Dr. Udayangani Kulatunga: Udayangani is a lecturer in Quantity Surveying at the School of the Built Environment, University of Salford. She has over seven years experience in teaching and research in Sri Lanka and in the UK. She is involved in both at undergraduate and post-graduate teaching. Udayangani completed her $\mathrm{PhD}$ in the area of performance measurement in construction research and development. Her research interests are performance measurement, disaster risk reduction, construction waste management, and construction procurement. Her research output is demonstrated by the number of publications done in both journals and international conferences.

Prof. Dilanthi Amaratunga: Dilanthi is the Professor of disaster management and the Director of the Research Centre for Disaster Resilience at the University of Salford, UK. Her research interests include performance management, disaster management, facilities management and knowledge transfer from research to teaching, education and training, and women in construction. She is the Co-Editor of International Journal of Disaster Resilience in the Built Environment and has extensive experience in leading international research collaborations. She has presented widely at International conferences, has led international workshops and seminars and working actively with the UN. 
Dr. Richard Haigh: Richard is a Senior Lecturer at the School of the Built Environment, University of Salford, UK and Programme Director for the School's MSc Disaster Mitigation and Reconstruction programme. He is Co-Editor of the International Journal of Disaster Resilience in the Built Environment and his research interest includes: adaptive capacity development; community based organisations and livelihood development; corporate social responsibility; stakeholder management; and, the conflict and built environment interface.

Received August 2010

Accepted November 2010

Final acceptance in revised form December 2010 